\title{
STATUS OF PUBLICATIONS IN JOURNAL OF NEPAL MEDICAL ASSOCIATION DURING 1991-2000: AN OVERVIEW - I
}

Paudel B $\mathbf{H}^{1}$

\section{ABSTRACT}

This is a "meta-analytical" study of publications in Journal of Nepal Medical Association (JNMA). The study aimed at investigating the quantitative status of publications in JNMA during 1991-2000, which could possibly be used as a feedback for improvement of journal quality. A total of 469 articles were classified according to their headings. They were sub-grouped into yearly, two-yearly (1991-1992, 1993-1994 etc), three-yearly (e.g., 1991-1993, 1994-1996 etc), and five-yearly (1991-1995, 19962000) basis. The proportions of articles within each sub-group across time from 1991 to 2000 were compared (e.g., 1991-1992 vs. 1993-1994 etc) using Fisher exact or chisquare test. The JNMA publications during 1998-1999 were also compared with JIMA (Journal of Indian Medical Association) publications. The results showed that the original articles and case reports were significantly less during mid nineties of the 20th century. The editorials increased significantly whereas the articles on 'health care' and 'clinical pharmacology' were decreased in the 2nd half of the decade. When the publications during 1998-1999 were compared with JIMA, the proportions of review and original articles in JNMA were significantly more. But the proportion of reviews relative to original articles was significantly less in JNMA as compared to JIMA. The JNMA was specially featured with articles on medical education, and health policy and planning whereas the JIMA had more articles of interest for general practitioners. In conclusion, the JNMA publications during the period of 1991-2000 were not consistent. The JNMA may need reconsideration of publication policy and to take measures to maintain constancy of its publications.

Key Words: meta-analysis, quality publication, quantity of publication.

1. Asst. Prof., Dept. of Physiology, B.P. Koirala Institute of Health Sciences, Dharan, Nepal.

Address for correspondence : $\quad$ Dr. B.H. Paudel, Assistant Professor, Department of Physiology

B.P. Koirala Institute of Health Sciences, Dharan, Nepal.

Phone : 025-2555-3118, Fax: 025-20251

Email: bhpaudel@lycos.com 


\section{INTRODUCTION}

This is a "meta-analytical review" of articles published in Journal of Nepal Medical Association (JNMA). Review of scientific reports in journals is an important aspect of getting feedback on publications. There is an excellent study reviewing the quality of publication of the New England Journal of Medicine. ${ }^{1}$ The JNMA is a non-indexed journal, and therefore an intuition to explore the recent status of its publications promoted the author to carry out this study, m other words, this is an attempt of "meta-analytical' introspective approach to quantitative status of JNMA publications. Thus, this study aimed at documenting the status of constancy of publications in the decade 1991-2000. $\mathrm{ft}$ was also aimed that the editorial committee, the authors, and the readers could possibly use the obtained results as feedback message for improvement of "quality" of publication in the journal by maintaining the quantity.

\section{METHODS}

All the JNMA issues of the decade i.e., 1991- 2000 were collected. A total number of 469 JNMA articles were checked. They were classified according to the headings as they appeared in the journal issues (Table 1). The articles were subgrouped into yearly (1991, 1992, etc), two-yearly

\begin{tabular}{|c|c|c|c|c|c|c|c|c|c|c|c|c|c|c|}
\hline \multicolumn{15}{|c|}{ Classification of Publications in JNMA 1991-2000 } \\
\hline \multirow[t]{2}{*}{ Year } & \multirow[t]{2}{*}{$\begin{array}{c}\text { Total } \\
\text { Articles }\end{array}$} & \multirow{2}{*}{$\begin{array}{c}\text { Clinical } \\
\text { Pharma } \\
\text { cology }\end{array}$} & \multirow{2}{*}{$\begin{array}{l}\text { Health } \\
\text { Policy/p } \\
\text { lanning }\end{array}$} & \multirow[t]{2}{*}{ Editorial } & \multirow{2}{*}{$\begin{array}{l}\text { Personal } \\
\text { View/mi } \\
\text { lestones }\end{array}$} & \multicolumn{2}{|c|}{$\begin{array}{l}\text { Original } \\
\text { Articles }\end{array}$} & \multirow[t]{2}{*}{$\begin{array}{c}\text { Case } \\
\text { Reports }\end{array}$} & \multirow[t]{2}{*}{$\begin{array}{c}\text { Short } \\
\text { Reports }\end{array}$} & \multirow{2}{*}{$\begin{array}{c}\text { CME \& } \\
\text { Med. } \\
\text { Edu. }\end{array}$} & \multirow[t]{2}{*}{$\begin{array}{l}\text { Health } \\
\text { Care }\end{array}$} & \multirow[t]{2}{*}{ Review } & \multirow[t]{2}{*}{$\begin{array}{l}\text { Com } \\
\text { ment }\end{array}$} & \multirow[t]{2}{*}{ Misc. } \\
\hline & & & & & & Total & $\%$ & & & & & & & \\
\hline 1992 & 26 & 1 & & & 2 & 15 & 57.69 & 3 & 1 & 1 & & 2 & & \\
\hline 1993 & 67 & & & & & 43 & 64.18 & 11 & & 4 & & 5 & & 4 \\
\hline 1994 & 44 & 1 & & 1 & 1 & 19 & 43.18 & 8 & 2 & 2 & 3 & 3 & 1 & 3 \\
\hline 1996 & 54 & & 1 & 4 & 5 & 20 & 37.04 & 2 & 1 & 1 & 4 & 6 & 9 & 1 \\
\hline 1997 & 77 & & & & 8 & 44 & 57.14 & 11 & & 3 & & 5 & & 6 \\
\hline 1998 & 47 & & 3 & & & 23 & 48.94 & 8 & & 4 & & 9 & & \\
\hline 1999 & 33 & & & 1 & & 17 & 51.52 & 8 & & 5 & & 2 & & \\
\hline 2000 & 38 & & & 3 & & 18 & 47.37 & 12 & & 2 & & 3 & & \\
\hline Sum & 469 & 8 & 4 & 9 & 19 & 239 & & 73 & 5 & 25 & 16 & 42 & 11 & 17 \\
\hline
\end{tabular}

(1991-1992, 1993-1994 etc), three-yearly (19911993, 1994-1996 etc), and five-yearly (1991-1995, 1996-2000) basis. The statistical test between publications across time was primarily focused on major articles (original, review) with greater research and practical significance. The proportions of articles within each sub-group (e.g., 1991-1992 vs. $1993-1994$ or $1991-1993$ vs. $1994-$ 1996 etc) of JNMA articles were compared using Fisher exact and / or chi-square test. Since the articles under the headings of personal view, short reports, medical education, comments etc appeared intermittently or with less quantity in the journal; they were not checked for statistically. The relative proportions of major articles were also compared with each other e.g., proportion of original articles versus proportion of case reports (Table 2). The proportions of JNMA articles were also compared with JIMA (Journal of Indian Medical Association) publications of 1998-1999 (Table 3).

\section{RESULTS}

\section{Five-year comparisons}

The 5-year sums of original articles were statistically not different ( $p=$ NS) between first and second halves of the last decade (1991-2000). The articles on clinical pharmacology did not appear in the journal in the second half of the decade. There was a significant increase $(p<0.05)$ in editorials in the second half of the decade. The articles under the heading of health care were decreased significantly $(\mathrm{p}<0.05)$ in the second half of the decade. The rest of the articles remained comparable between the two halves of the decade (Table 2). 
Table 2. CLASSIFICATION OF PUBLICATIONS OF JNMA 1991-2000

\begin{tabular}{|c|c|c|c|c|c|c|c|c|c|c|c|c|c|}
\hline \multirow{2}{*}{$\begin{array}{c}\text { Type of } \\
\text { Publication }\end{array}$} & \multicolumn{6}{|c|}{ Two-year Profile } & \multicolumn{4}{|c|}{ Three-year Profile } & \multicolumn{3}{|c|}{ Five-year Profile } \\
\hline & $\begin{array}{c}1991 \\
- \\
1992 \\
\end{array}$ & $\begin{array}{c}1993 \\
- \\
1994 \\
\end{array}$ & $\begin{array}{c}1995 \\
- \\
1996\end{array}$ & $\begin{array}{c}1997 \\
- \\
1998 \\
\end{array}$ & $\begin{array}{c}1999 \\
- \\
2000\end{array}$ & $\mathrm{p}$ value & $\begin{array}{c}1991 \\
- \\
1993\end{array}$ & $\begin{array}{c}1994 \\
- \\
1996 \\
\end{array}$ & $\begin{array}{c}1997 \\
- \\
1999\end{array}$ & $\mathrm{p}$ value & $\begin{array}{c}1991 \\
- \\
1995 \\
\end{array}$ & $\begin{array}{c}1996 \\
- \\
2000 \\
\end{array}$ & $\mathrm{p}$ value \\
\hline Total Articles & 51 & 111 & 112 & 124 & 71 & & 118 & 156 & 157 & & 220 & 249 & \\
\hline $\begin{array}{c}\text { Clinical } \\
\text { Pharmacology }\end{array}$ & 2 & 1 & 5 & & & & 2 & 6 & & & 8 & & P0.01 \\
\hline $\begin{array}{l}\text { Health Policy } \\
\text { and planning }\end{array}$ & & & 3 & 1 & & & & & & & & & \\
\hline Editorial & & 1 & 4 & & 4 & & & 5 & 1 & & 1 & 8 & $\mathrm{P}<0.05$ \\
\hline Personal View & 4 & 1 & 6 & 8 & & & 4 & 7 & 8 & & 6 & 13 & \\
\hline $\begin{array}{l}\text { Original } \\
\text { Articles } \\
\end{array}$ & 31 & 62 & 44 & 67 & 35 & $\mathrm{p}<0.05$ & 74 & 63 & 84 & P0.01 & 117 & 122 & NS \\
\hline Case Reports & 6 & 19 & 9 & 19 & 20 & $\mathrm{p}<0.05$ & 17 & 17 & 27 & $\mathrm{P}<0.05$ & 32 & 41 & NS \\
\hline Short Reports & 1 & 2 & 2 & & & & 1 & 4 & 4 & & 4 & 1 & \\
\hline $\begin{array}{c}\text { CME \& Med. } \\
\text { Education }\end{array}$ & 2 & 6 & 3 & 7 & 7 & & 6 & 5 & 12 & & 10 & 15 & \\
\hline Health Care & & 3 & 13 & & & & & 16 & & & 12 & 4 & \\
\hline Reviews & 2 & 8 & 13 & 14 & 5 & NS & 7 & 16 & 16 & NS & 17 & 25 & NS \\
\hline Comment & & 1 & 10 & & & & & 11 & & & 2 & 9 & \\
\hline Miscellaneous & & 7 & 2 & 6 & & & 6 & 5 & 6 & & 10 & 7 & \\
\hline
\end{tabular}

\section{Three-year comparisons}

There was significant decrease $(\mathrm{p}<0.01)$ in original articles during the middle third of the decade in comparison to both the extreme thirds. But the case reports and review articles remained comparable $(p=$ NS) between the thirds (Table 2).

\section{Two-year comparisons}

The number of original articles was significantly decreased $(\mathrm{p}<0.05)$ during the middle of the decade and similar drop was seen in case of case reports $(\mathrm{p}<0.05)$. But the review articles remained steady during the decade. The proportions of original articles, case reports and reviews remained fairly constant ( $p=N S$ ) throughout the decade. However, the total number of articles showed decreasing trend towards the end of the decade (Table 2).

\section{Comparison between JNMA and JIMA (Table 3)} In comparison to JIMA the number of original articles in relation to total was significantly high
( $\mathrm{p}<0.01$ ) in JNMA during the 1998-1999 period. Similarly review articles in JNMA were significantly high. The numbers of case reports and review articles between the journals were comparable $(\mathrm{p}=\mathrm{NS})$ (Table 3$)$.

Table 3. CLASSIFICATION OF PUBLICATIONS IN JIMA 1998-1999

\begin{tabular}{|c|c|c|c|}
\hline \multirow[t]{2}{*}{ Type of Articles } & \multicolumn{2}{|c|}{ Journal } & \multirow{2}{*}{\begin{tabular}{|c|}
$\begin{array}{c}\text { Significance } \\
\text { (p value) }\end{array}$ \\
\end{tabular}} \\
\hline & JNMA & JIMA & \\
\hline Total Articles & 80 & 219 & \\
\hline Editorial & 1 & 21 & \\
\hline Original Articles & 40 & 52 & $\mathrm{p}<0.01$ \\
\hline Special / Review Articles & 11 & 42 & NS \\
\hline Preliminary Reports & & 11 & \\
\hline Practitioners Series & & 17 & \\
\hline Case Reports & 16 & 39 & NS \\
\hline GP Forum & & 8 & \\
\hline Current Topic & & 7 & \\
\hline CME \& Medical Education & 9 & & \\
\hline Health Policy / Planning & 3 & & \\
\hline Miscellaneous & & 22 & \\
\hline
\end{tabular}


The proportion of review articles was significantly less $(\mathrm{p}<0.001)$ in comparison to original articles in JNMA, whereas JIMA had no such difference $(\mathrm{p}=\mathrm{NS})$ in. The other categories of articles (less addressed or entirely new in JNMA) viz., editorial, preliminary report, practitioner's series, GP forum, and current topic were regular phenomena for JIMA. The proportions of individual articles were higher in JNMA but the total number of the publications was substantially less than that of JIMA during the 1998-1999 period (Table 3).

\section{DISCUSSION}

This study is unique in its nature. This is a quantitative review of JNMA publication during the last decade of the 20th century aiming at 'qualitative' improvement of the journal, Selection of journals was based on the availability of issues of the journal between 1991 and 2000. The total number of articles published, especially the original ones, was not continuous throughout the study decade. There was a drop in its publications during middle of the decade i.e. during 1994-1996 (Fig.1). The cause for this is not known and this study did not aim at that. The cause should be found out so that such remarkable fluctuations in number of publications can be prevented in future. There was a consistent increment in editorials, which could be a good sign because it may give direction or areas of research priority. However, there was decrease in articles under the heading "health care' with some compensatory increment in articles related to health policy and planning. The articles on clinical pharmacology did not appear in the JNMA in the $2^{\text {nd }}$ half of the decade without significant increase in reviews or updates pertaining to pharmacology or in general.

The proportion of reviews or special articles pertaining to a special topic in JNMA was comparable to JIMA but their absolute number was remarkably low in JNMA. ft appears to be because of frequent (monthly) publication of JIMA in contrast to JNMA (every 3 months). Simple adjustment of frequency would result in comparable results. In other words, if JNMA were published with same frequency, there would not have been any difference. Considering the small number of scientific journals in Nepal, the number of articles should have been more in it. In recent years there has been an increase in biomedical journals from

\section{Pattern of Number of Original Articles Published in JNMA during 1991-2000}

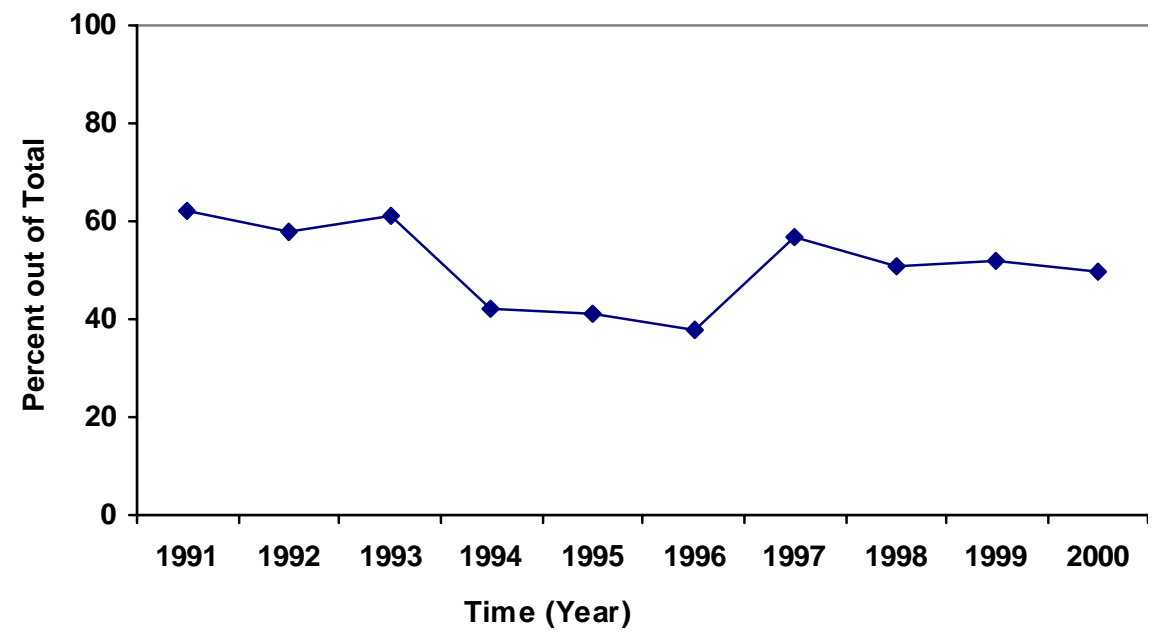


the newly established medical institutions in the country. However, an increment in publication was not reflected in JNMA though it has been noticed that there is general increment in publication in Nepal in last 2-several years. ${ }^{2}$ The topics of interest for general practitioners were not addressed in JNMA but were a regular feature of JIMA. It may be beneficial to add this type of articles in JNMA too after getting opinions from the contributors and readers. But the JNMA had some special features of having extra publications on CME, medical education, and health policy and planning. The topics were not included in JIMA probably India has separate journals for such subjects.

Here one may easily ask why JIMA was selected for comparison. It was found best comparable with JNMA because of similarity in disease pattern between two countries and types of publications. A few issues of JNMA and JIMA were missing which may be considered a limitation of the study. In the author's opinion, since the data are compared after normalisation by taking proportions the missing data probably would not have affected the result even if they were incorporated. Thus the number of issues and time interval considered are adequate enough to draw some conclusion that can be used as a valid feedback on the number of publications in the journal.

In summary, the number of original articles and adjustment of frequency of publication indicates that JNMA is better than JIMA. However, the JNMA publications during the period of 1991-2000 were not consistent and the absolute number of the articles was relatively less in comparison to similar journal of neighbouring country. Therefore, the JNMA may need reconsideration of publication policy and to take measures to increase and maintain its number of publications.

\section{REFERENCES}

1. John C Bailar III, Thomas A Louis, Philip W Lovori, Marcia Polansky. A classification for biomedical research report. In Medical Uses a/Statistics (Eds. J.C. Bailar III and F. Mosteller) . NEJM Books, Boston; 1992.

2 Editorial. Nepal Joumal of Science and Technology; 1999; 1.

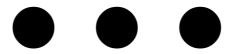

